\title{
Gender, Alterity and Human Rights: Freedom in a Fishbowl -
}

This book is about the possibility of freedom in the aftermath of the critique of human rights. Human rights are axiomatic with freedom, quite specifically liberal freedom. I invoke the metaphor of the fishbowl as representing the liberal constellation that shapes and disseminates mainstream human rights advocacy and scholarship as well as particular understandings of freedom. Freedom within a liberal paradigm is envisaged as an external pursuit, involving the accumulation of rights by a rational, finite, and individual subject, and void of political preoccupations and outcomes. I demonstrate how the critical legal project, including postcolonial and feminist interventions, has successfully dismantled the façade of this claim exposing the substantive political effects, contingency of universality, and hierarchy of the subject that structures human rights. Building on the existing critiques, I illustrate how human rights emerge as a governance and regulatory endeavour specifically in relation to gender and alterity, and how more rights for women, sexual and religious minorities have not necessarily produced more freedom for these constituencies.

The central concern that this book seeks to address is: What happens when the faith in human rights as a liberal freedom project is so substantively eroded? If human rights cannot give us what we want - namely, freedom - then what can? One answer lies in foregrounding non-liberal, not illiberal, alternative registers and understandings of freedom, and examining the futurity of human rights in such a pursuit.

\section{What is the argument?}

My provocative argument is that the positioning of human rights as indispensable central instruments in struggles for freedom cannot survive the critiques, which have exposed the discursive operations of human rights as irrefutably hegemonic; a governance project primarily concerned with ordering the lives of non-European peoples, subaltern subjects, and 
creating the conditions for the exponential flourishing of the neoliberal market. This scholarship has provincialized the universal claims of international human rights law.

This book is not a critique of liberalism, but builds on the critiques of liberal freedom and the work that it does in the context of human rights, specifically in relation to gender and alterity. Critical legal scholarship has problematized the extractive and appropriative aspect of the missions proclaimed progressive sensibilities. It has revealed how the characterisation of human rights as an international emancipatory endeavour and bulwarks for vulnerable and marginalised subjects, obscures the ways in which it has been shaped and continues to be informed by the historical legacies of Empire, colonial-era conditioning and policies, including assumptions about the 'Other' as culturally, politically and economically subordinate or inferior. Human rights are not only implicated in the production of inequalities and reproduction of multiple marginalisation and exclusion, but also serve as tactics and vehicles of governance and domination in the contemporary processes of globalization, neoliberalism and thriving markets.

The first half of the book illustrates the ways in which human rights proscribe freedom in the context of campaigns for decriminalising homosexuality and legalising samesex marriage; ending violence against women, focussing specifically on interventions on trafficking, as well as gender peace and security in conflict and post-conflict situations; and responses to the Islamic veil bans in liberal democracies, especially the decisions of the European Court of Human Rights that have upheld these bans. Drawing on existing critiques of rights in legal scholarship, the analysis demonstrates how human rights emerge as a form of governance in relation to gender and alterity that operate through normative prescriptions, which bind even as they purport to free, and also establish a hierarchy of the subject of human rights: who is human and who is not; who qualifies for rights and who does not. 
In light of the well-established and familiar critiques of human rights, the question arises as to why critical scholarship has tended to offer reformulations and, somewhat awkwardly (and unsuccessfully), sought to reinstall the project of human rights through proposals of pragmatic renewal and reinvestment. Rather than theorizing strategies of empowerment that take us further in the direction of freedom, these proposals speak more to the anxiety and fear about 'letting go' of a project that has been so cherished over the past half-century. The theoretical turn back to human rights is in fact reflective of the anxiety that accretes around the notion of the epistemic void that, from the liberal perspective, would presumably result from any subversion or deconstruction of the existent rights framework.

This recursive move is configured as pragmatic reform, renewal and reinvestment in human rights, which persists with a commitment to rights deployment as a mechanism for procuring lasting freedom. Having problematized the liberatory role and exposed the conceit of human rights as the central device for freedom, the critique then pulls back from the brink of exploring alternatives and instead, seeks to retrieve the transformative vestiges of human rights from endless circumambulations within the fishbowl. At one level, these critical repostulations open rights discourse to different readings, and invoke its potential for different future uses, meanings and possibilities. However, freedom is not among those uses. Such efforts do not confront the illusion that underlies the despair and scepticism overtaking progressive politics as its adherents acknowledge that, in terms of delivering on the promise of freedom, human rights have indubitably proved to be a grievous illusion - one that should prompt a turn away from, rather than a turn back to, the human rights schema, and towards the exploration of alternative conceptualizations of freedom.

Unfortunately, the contingency of rights, freedom and subjectivity exposed by critical legal scholarship has not proved to be a starting point for more creative analysis and explorations. The project remains partly defined by a powerful mistrust of non-liberal 
epistemological traditions and their different understandings of freedom that are invariably viewed from within the fishbowl as an aggressive and regressive threat to its hegemonies. This fear is informed partly by an erroneous assumption that there are no workable or sustainable alternatives outside of a liberal formulation or reformulation, and that any ventures beyond the liberal fishbowl are nihilistic and defeatist. A key argument that is made in this book is that this persistent faith in human rights that remains tethered to freedom in a fishbowl despite the critiques is a form of what Berlant calls 'cruel optimism' - a desire or need to retain faith in systems and interventions in which so much hope has been invested despite material evidence to the contrary; it is this faith that represents a nihilistic move that can take us no further in the direction of freedom (Berlant 2011).

In the second part of the book I explore the imaginary possibilities that open in the aftermath of critique by centring and examining articulations of freedom available in nonliberal, alternative epistemologies. The argument draws partly on the radical thinking of critical Western scholars such as Michel Foucault and his lessor know work on "political spirituality" in the context of the early days of the Iranian Revolution, that was consistent not only with his search for an alternative logic by which to rethink, and re-conceptualise revolution as a phenomenon that enables both internal as well as external change but also with the preoccupation in his later work on the self(McWhorter 2003); the inquiry of Eve Sedgwick, a central figure in critical queer/feminist scholarship, into Mahayana Buddhist epistemology as offering an alternative model of meaningful freedom, and her categorical claim that deconstruction inevitably leads to non-dualism and oneness that underscores this tradition (Sedgwick 2003; Sedgwick 2011); as well as postcolonial feminist scholar Saba Mahmood's pathbreaking work on the veil as an expression of freedom - that is - freedom experienced through the veil rather than from the veil, something that cannot not be understood within the liberal imaginary or the fishbowl (Mahmood 2005). 
I also draw on nonliberal philosophical and agnostic spiritual traditions such as the ecstatic registers of Persian Sufism, where freedom is expressed in intensely affective and passionate release, and also engage in a close reading of the nonliberal, subcontinental episteme of nondualism - Advaita, 'not two' - to demonstrate how an alternative register is not adversarial or irrelevant to human rights, even though its inscription of selfhood and of the processes of being and becoming may seem incommensurable with the parameters of subjectivity as enunciated and affirmed within the human rights project. In each instance, what becomes evident is that meaningful freedom is possible primarily through selftransformation and self-reflection. I end the book with examples of what a turn away from human rights as a freedom project and towards alternative registers, might look like and what is the futurity of human rights within such a vision.

The questioning of human rights as a freedom project and the call for a turn towards nonliberal pursuits is of course full of trip wires. It is important to clarify that this work does not imply support for cultural relativists, or ideologues of various persuasions, who foment collective practices that are inhuman and antihuman and who might embrace the arguments presented as a justification for refuting the human rights project and embracing cultural orthodoxies. In fact, the argument seeks to occupy the semantic and political 'nonliberal' space that has all too often and easily been ceded to reactionary forces and orthodoxies by progressive, leftist, postcolonial and feminist forces out of fear that it may mark them as 'religious' or unsecular. Nor does the proposed shift require abandoning human rights as several scholars have proposed. The analysis is underpinned by a call for a more mindful and diligent approach, one that consciously takes a step back and objectively evaluates what has been gained through the ethics and mechanics of the current model of human rights advocacy, and what has been - perhaps irretrievably - lost. 
Freedom in a Fishbowl treads a careful path that does not abandon the project of human rights, which needs to be continuously engaged primarily because it is an important arena of power and for that reason should not be relinquished. The argument is that meaningful freedom cannot be secured through the pursuit of human rights. The successful demands for human rights by gender or sexual subalterns or cultural 'others' can be disruptive but they have not been able to dismantle or transform the normative terms on which freedom is based. In fact, recognition through rights discourse incorporates the subject into the coercive apparatus of a justice regime that continues to be informed by the historical legacies of colonialism, structural adjustments, market reforms and the reduction of life to economic values.

This book's central task is to scrutinises the work that liberal freedom does in the context of human rights in light of the critiques. Rather than offer solutions, it offers a direction for freedom seekers to explore. It is preoccupied primarily with how nonliberal freedom can provide an avenue for pro-scribing the wheel-ruts into which human rights have become trapped and bring to an end the interminable circumambulations within the liberal fishbowl that cannot move us any further in the direction of meaningful freedom. My critique of human rights and its proven limits together with its invitation to turn to the nonliberal is intended to provoke our reflective rather than our reflexive responses.

\section{References}

Berlant, Lauren. Cruel Optimism. Durham, NC: Duke University Press, 2011.

Mahmood, Saba. Politics of Piety: The Islamic Revival and the Feminist Subject. Princeton, NJ: Princeton University Press, 2005.

McWhorter, Ladelle. 'Foucault's Political Spirituality.' Philosophy Today 47, Suppl. (2003): 39$\underline{44}$.

Sedgwick, Eve Kosofsky. 'Pedagogy of Buddhism.' In Touching Feeling: Affect, Pedagogy, Performativity, pp.153-81. Durham, NC: Duke University Press, 2003.

Sedgwick, Eve Kosofsky. 'Reality and Realization.' In The Weather in Proust, edited by Jonathan Goldberg, pp.206-15. Durham, NC: Duke University Press, 2011.
Formatted: Indent: Hanging: $0.5 \mathrm{~cm}$, Space After: $3 \mathrm{pt}$, Line spacing: single

Formatted: Font: $12 \mathrm{pt}$ 
Formatted: Indent: Hanging: $0.5 \mathrm{~cm}$, Space After: $3 \mathrm{pt}$,

Line spacing: single 